\title{
Effective Working Capital Management in Small and Medium Scale Enterprises (SMEs)
}

\author{
Kehinde James Sunday \\ Dept of Accounting and Finance, Lagos State University Ojo, Nigeria \\ E-mail: pastorkehindebox@yahoo.com
}

Received: November 15, $2010 \quad$ Accepted: August 10, $2011 \quad$ doi:10.5539/ijbm.v6n9p271

\begin{abstract}
The need to main effective working capital management within Small and Medium Scale Enterprises (SMEs) remain pivotal to solvency and liquidity of SMES. Most SMES do not care about their working capital position, most have only little regard for their working capital position and most do not even have standard credit policy. Many do not care about their financial position, they only run business, and they mostly focus on cash receipt and what their bank account position is. For the purpose of this study, Standard working capital ratios were used to measure the effectiveness of working capital in the selected firms. The firms selected show signs of overtrading and illiquidity, concerns was on profit maximization without taken cognizance of payment of creditors. The firms exhibit low debt recovery over credit payment. It is recommended that for SMEs to survive within Nigeria economy they must design a standard credit policy and ensure good financial report and control system. They must give adequate cognizance to the management of their working capital to ensure continuity, growth and solvency.
\end{abstract}

Keywords: Small and medium scale enterprises (SMEs), Working capital management, Liquidity, Solvency

\section{Introduction}

The Small and Medium Scale (SME) business remain the most dynamic force and agent of economic growth and development of a nation. The small and medium scale enterprises generates at least $60 \%$ of the USA GDP (Ovia, 2001) In Nigeria, the SMEs are all around us, the fact that only few amount is required to start an SMEs make it the most popular term of business. The SMEs constitute the major breakthrough in several emerging sectors. Most breakthroughs in (IT) in the U.S.A were propelled by SME. Microsoft Disk Operating System (MS Dos) that enabled about $80 \%$ of the world PCS to operate was developed in 1980 by Bill Gates and Paul Allen when their company was a small scale enterprise. In India, IT industry exported about 6 billion software's and related services in year 2000. This amount is just a little less than Nigeria's oil revenue of $\$ 9$ billion for the same period (Ovia, 2001).

However, several SME in Nigeria fail in a little time after they are started; most fail due to poor financial management especially the working capital management. Most SMEs do not engage their working capital in such a way as to enjoy maximum profit (Geoffrey, 1969). The combination of debtors' management strategy, cash management, account payable (or creditors) and most importantly stock management strategy left much to be desired by the SME.

This work will evaluate various working capital management strategies and their effective application by SME; most small businesses (SMEs) do not manage their short-term fund effectively. The net working capital are most times ignored, thus, they run into insolvency. The need to evolve a proper working capital management is important for good solvency and liquidity of the firm.

The study is on working capital management in small and medium scale enterprises, we shall look at this in six formats namely.

1) Concept of small and medium scale business.

2) Concept of finance in SMEs.

3) Working capital management concept.

4) Theory of working capital and small scale business

5) Research question.

6) Model specification and analysis.

7) Conclusion and recommendation. 


\section{Objectives of the Study}

1) To evaluate the effect of working capital management on the solvency and liquidity of SMEs.

2) To evaluate other method of debt payments than payment out of cash.

3) To evaluate or establish an optimal working capital cycle that will encourage payment of debtor using short term sources of fund.

4) To evaluate and propose appropriate working capital management policy for SMEs in Nigeria

\section{Literature review}

\section{Concept of small and medium scale business}

Small and medium scale enterprise have been defined in various ways by various people and government agency just as It has been worked on in various ways by different nation. Micro business has been recognized, a small firm is recognized as well as medium scale business. However, our work will cover both the micro business or small-scale business and the medium scale business.

\section{Bolton Committee (Britain 1971)}

The most comprehensive study of small firms in the United Kingdom was that carried out by the Bolton Committee (1971). The committee defined "small firms" "as one with not more than 200 employees". However, this could only relate to those firms in the manufacturing sector, thus, the below categorization are firms operating small business and they are as follows, as defined by the Bolton committee;

\section{Industry}

Manufacturing

Retailing

Wholesale trades

Construction

Mining/quarrying

Motor trade

Miscellaneous services

Road transport

\section{Definition}

200 employees or less

Turnover (sales) $£ 200,000$ p.a or less

Turnover $£ 200,000$ p.a or less

25 employees or less

25 employees or less

Turnover $£ 100,000$ p.a or less

Turnover $£ 50,000$ p.a or less

5 vehicles or less.

Source: Bolton Committee (Britain, 1971)

\section{Industry}

Another attempt at defining what a small business means is contained in the United States of America Committee for Economic Development (CED) which stated that "A small scale business is one which possesses at least two of the following four characteristics".

1) Management: Usually the managers are also the owners.

2) Capital is supplied and the ownership is held by an individual or small group.

3) The area of operation is mainly local.

4) The relative size of the firm within its industry must be small when compared with biggest units in its field. USA: Committee for Economic Development

In Japan, a small scale industry is defined according to the type of industry for small medium industry in manufacturing; it is defined as those with $£ 100$ million as paid up capital and 300 employees while small scale business in wholesale trade will have $\$ 30$ million paid up capital and 100 employees.

Also, in United State of America, the Small Business Administration (SBA) defined small business as an independently owned and operated firm, which is dominant in its' field and having no more than:

1. $\$ 8$ million annual sales (for service business);

2. $\$ 7.5$ million annual sales (for retail business);

3. $\$ 22$ million annual sales (for wholesale);

4. $\$ 9.5$ million annual sales business;

5. Yearly average of 1500 employees (manufacturing)

In Nigeria, small and medium scale business has been variously defined by various organizations, bodies and in various forms (Anderson, 1982, Adeleke, 2003).

In Nigeria, the Small Scale Industries Association (1973), defined small business as "those having investments (i.e. capital, land, building and equipment up to $\mathrm{N} 60,000$ (Pre-SAP value) and employing no more than fifty persons".

The Federal Ministry of Industries defined small business as those enterprises that cost no more than $\mathbb{N 5 0 0 , 0 0 0}$ 
(Pre-SAP value) including working capital, to set up.

The Center for Management Development (CMD) defined small business in their policy proposal submitted to government in 1982 as a manufacturing, processing and service industry involved in a factory or production type of operation, employing Lip to 50- full-time workers with investment on plant and machinery (excluding land and buildings) which shall not exceed $\mathrm{N} 500,000$ power plant and machinery are used in its' operation.

The Central Bank of Nigeria 1996 monetary policy guidelines defined small scale enterprises as "enterprises whose total cost, excluding cost of land but including working capital does not exceed N10 million".

The National Economic Reconstruction Fund puts the ceiling for small scale business to al investment at $\$ 10$ million. The Company and Allied Matter Decree 1990 Section 37b (2) define a small company as one with:

a) Annual turnover of not more than $\mathrm{N} 2$ million.

b) Net assets value of not more than $\mathrm{N} 1$ million.

It needs to be stated that no simple definition could be absolute and total in defining what a small scale business is, several nations and bodies define small and medium scale business in various ways however, a good definition, among other things, should indicate the extent to which the scope has expanded or shrank over time within a given economy, small scale industries cannot be defined once and for all. The changing pattern of overall industrial or economic growth is bound to affect the content or limits of such a definition. In Nigeria, investment ceiling in machinery and equipment alone in the small industry sector has been raised several times in the past 16 years. In 1972, the limit was set at $\mathrm{N} 50$, 000. In 1973/75 period, this was raised to $\mathrm{N} 60,000$ during the third national development plan (1975-80), the government in 1977 raised the ceiling to $\mathbb{N} 150,000$. Currently, the official upper limit set by the federal government stayed at $\mathrm{N} 20$ million, but without the emphasis on the maximum number of employees which was set at 49 in 1972.

It needs to be stated that the roadside enterprises in the informal sector are not the same as the much talked of and highly publicized small scale industries which are registered by the Ministry of Tracie, Commerce and Industries and usually assisted by the federal and state governments under the auspices of the Small Scale Industries Scheme (SSI). The flexibility in definition of SMES have been acknowledged by the Centre for Management Development (CMD) in their research work for over 15 over years in all parts of Nigeria. Thus, they stated that the "issue of SMES is a continuous affairs according to economic growth stage and development level. (Lawal, 1998).

The National Council on Industry (NCI) stream-line the definition of industrial enterprises to bring in uniformity and provided for its review every four years. The definitions were revised in 1996 as follows:

a) Cottage industry; enterprise with total cost (including working capital but excluding cost of land), not more than $\mathrm{N} 1$ million, with a labour size of more than 10 workers.

b) Small-scale Industry; enterprise with total cost (including working but excluding cost of land) above N1 million, but exceeding N40million with labour size of between 11 and 35 workers.

c) Medium-scale industry: enterprises with a total cost (including working capital but excluding cost of land) above N40 million but not exceeding N150 million, with a labour size of between 36 and 100 workers; and

d) Large scale industry: enterprises with cost (including working capital but excluding cost of land) above N150 million and a labour size of over 100 workers (Nnanna, 2005).

Thus, definition of a small-scale business ranges between identifying the capital structure, ownership structure, labour structure, and marketing/turnover structure of the firm.

\section{Concept of Finance in Small and Medium Scale Enterprises}

The small and medium scale business have been Identified as the pivot of growth in the economy of Nigeria. Several methods and schemes of finance exist for the small and medium scale business. This ranges from private and personal financial sources to the corporate and near corporate finance.

The basic corporate finance strategy of the SMEs remains government financial support of the SMEs (Ogundele, 2004). The Bolton committee also has identified these various sources of finance of the SMES, as said; this could basically be categorized into three basic functional group, these include:

1. Private and personal finance

2. Corporate finance

3. Near corporate finance

Private and Personal Finance

The private finance both the finance of fixed assets and the finance of the current assets. The vital strategic roles of current asset finance remain that of liquidity provision and prevention of insolvency of firm (Bumiro, 2001).

The private and personal source of finance according to the Bolton Committee includes: 


\section{Personal Savings}

Small firms tended to have to rely rather more heavily on their savings than did large companies but the most rapidly growing firms in both groups tended to be self-financed to a lesser extent than average SMEs.

Kehinde and Abiola (2005) have also identified personal saving as the key source in finance of micro and small business, especially at the start-up stage.

\section{The Corporate Finance Scheme}

The various institution of finance has identified with the finance of small scale firms. The small and medium scale enterprises for growth purpose rely considerately on bank loans. In Nigeria there have been various scheme meant to provide institutional finance for SME, they include Nigerian Bank for Commerce and Industry (NBCI) finance. The bank is to administer loans to the small scale industries in the country. In 1988 the government provided $\mathrm{N} 10$ million to the states, through the Bank for the development of industrial estate

In 2002, the government in the annual budget also instructed the commercial bank to set aside certain proportion of the profit before tax of their firm as equity participation in the small business.

\section{Near-Corporate Finance}

Today, many and almost the large proportion of SMEs are financed by the corporative society. Most people join the corporative society to raise short and long term finance. The entrepreneur must be member of the corporative society to obtain the loan. Most times the society gives twice the saving of the individual in the society. There may not be a serious collateral requirement once the entrepreneur is a member of the society.

\section{Current Asset Finance}

Financing the current asset of the firm remains an important aspect of this work. The current asset of the firm could be provided for by seeking and gaining indirect finance through account payable and other loan facilities.

\section{Micro Credits}

Is the financing of entrepreneurial ventures in the informal sector without material collateral but guaranteed by a peer group where each member has a stake in the form of savings. The micro credits are identified with micro credit.

\section{The Traditional Financial Life Cycle of the Firm}

At various stages of growth, different level and format of finance exist that can be exploited by the SME's owner.

The traditional financial life cycle of the firm, this includes the following:

Traditional financial life-cycle of the firm:

Stage Source of Finance

Inception Growth I

Growth II

Growth III

Maturity

Decline
Owners resource as above plus: retained profit, trade credit, bank loans and overdrafts, hire purchase, leasing

As above plus; long term finance from Finance gap financial institutions e.g. ICFC

As above plus; new issue market

All sources available

Withdrawal of finance firm take-over, Failing ROI share repurchased(es) liquidation

Failing ROI
Potential Problems

Under capitalization "over-trading" liquidity crises

Loss of control

Maintaining ROI

This traditional view of the financial life cycle of the firm, is as found for example in the finance text by Westonard Brigham.

Financial Management in Small and Medium Business

The financial manager obviously is of high import to the survival of the firm both in the short and long run of the life of the business. The financial manager provide some basic functions, Kehinde and Abiola (2005) have identify some of this functions as follows:

1) Financial Decision: The financial manager is responsible for financial decision, the best way to finance a firm. The financial manager must ensure maximum mixture of debt and equity in financing the firm. So as to ensure maximum returns to the business owners.

2) Investment Decision: The financial manager is assumed to be able to select the most profitable investment portfolio that will reduce to bearest minimum the risk of finance and ensure maximum return to the business owner(s). 
3) Dividend Policy: The financial manager is saddled with the responsibility of deciding the dividend policy of the firm. In a small scale business the responsibility of the financial manager would include that of identifying how to distribute the profit from the venture to the various owner(s).

4) Working Capital Management: It is the totality of management of cash, debtor, prepayments, stocks, creditors, short term loans, accruals, etc to ensure profitability of the firm. It is the management of the current asset and liability of the firm. The financial manager most time in small scale business is to ensure effective working capital and prevent insolvency and liquidity problem in the firm. The effective working capital management remains the main work to be done by the research work as it applies to small and medium scale business.

5) Financial Control and Reporting: It is the duty of the financial manager to ensure effective financial control and reporting in the business. There should be physical control of assets, and ensuring the solvency of the firm.

6) The scope and role of financial manager in the firm have been narrowed down to basic approaches as follows:

1. The traditional approach.

2. The managerial approach.

3. The new approach.

\section{The Traditional Approach}

According to this approach, the scope of the financial manager are confined to raising of funds (Kehinde and abiola, 2005), during major events (Such as promotion, recognition, expansion) in the life of the firm. The financial manager has the basic obligation of ensuring that the firm has enough cash to meet its obligations.

A notable feature of the traditional approach on financial manager's duty is the assumption that the financial manager has no concern in the decision of allocating the firm's funds. The problem of the approach is that much emphasis is placed on long term financing to the detriment of working capital management.

\section{The Managerial Approach}

The change in the business situation in the mid 1950, made the traditional approach to outlive its usefulness. The increase in market, the population growth, the management efficiency and future, during and after the mid 1950s necessitated efficient and effective utilization of the firm's resources. Consequently, financial management approach and scope markedly changed. The emphasis shifted from episodic financing to the managerial financing functions from raising of funds to include efficient and effective use of funds. This approach includes profit planning function. The term profit planning refers to operating decisions in the area of pricing, volume of output and the firm's selection of productive assets.

\section{New Approach}

This approach derive it impetus from the Lord Keynes's general theory. The core of the new theory, as applied to the business finance is found in the macroeconomic concept that level of aggregate economic investment depends on two factors viz: The additional expected rate of return on investment (marginal efficiency of investment) (Anao, 1990; Charles, 1992).

Keynes defined marginal efficiency of capital as ratio between the prospective yield of additional capital goods and their supply price i.e.

$\mathrm{E}=\underline{\mathrm{Y}}$

$P$

Where $=$ Marginal efficiency of capital

$\mathrm{Y}=$ The estimated yield of the capital asset

$\mathrm{P}=$ The supply price of the assets respectively or the original cost of investment.

The marginal efficiency of capital (e) is considered an important determinant of whether an entrepreneur should or should not take interest (r). Anderson D. (1982) opined that the entrepreneur will optimize his profit if he continues to take up additional investment until $\mathrm{e}=\mathrm{r}$.

Basically, according to Geoffrey (1969) the function of the financial manager is to review and control decisions to commit or recommit funds to new or on-going uses. Thus, in addition to funds, financial manager is directly concerned with production, marketing and other enterprises activities whenever decisions are made about the acquisition or distribution of assets.

\section{Working Capital Management}

Working capital is that proportion of a company's total capital which is employed in the short term operations. Geoffrey and Elliot, (1969) stated that working capital is customarily divided into two categories: Gross and Net.

Gross Working Capital is the sum total of all current assets, while Net Working Capital is the difference 
between current assets and current liabilities.

\section{The Gross Concept}

It is the totality of the current assets of the business which includes account receivable, cash, short-dated securities, bill receivable and stock. The gross concept advocates that a firm should possess working capital just adequate and sufficient to meet the firm's operating cycle. It ensures that excess investment in cash is avoided, since excess investment in cash result in excess liquidity resulting in lost of income or profit. This is called optimal level of investment in current assets. Excess investment in current asset is avoided.

The gross concept also emphasis availability of basic sources or fund

\section{The Net Concept}

This emphasis continuous liquidity of the firm, the concept advocates a finance of the working capital by a permanent sources of funds e.g. shares, debenture, long term debt, preference share capital retained earnings, etc, the net concept advocate the efficient mix of long term and short term sources of financing working capital.

\section{Current Asset Management}

The current asset of a firm is the totality of asset which expectation or turnover period is within a year. It is a constituent of the working capital of a firm. It needs to be stated that the working capital of a firm is the totality of the current asset and current liability of the fir (Beeley, 1973).

The current assets constitute the application of fund while the current liabilities constitute the source of fund to the firm.

The current assets are the assets used for the day-to-day manufacturing and or trading activities of a business. It represent fund that are invested in the short-term operations of the firm. Out of all possible investments a company could make current assets and those which can be expected to be turned over into cash within a twelve-month period. These assets include:

a) Stock: Finished goods, work-in-progress (W.I.P) raw materials.

b) Account receivable (Debtors).

c) Tax reserve certificate.

d) Payments in advance.

e) Short-term investments.

f) Cash (at bank, and in hand).

\section{Problem of the study}

The SMES must ensure strategic cash flows against its needed cash outflow; this is a function of effective working capital management. In managing the working capital of a firm especially the small business, the acute shortage of fund needed for growth remain a subject of strategic financial management function. The small business normally encounters the following problem in regard to their working capital management.

1) The high rate and threat of insolvency in small business most time lend itself to poor and ineffective working capital management. A further problem is the question of volume and level of current debt, which a firm can manage and afford (Geoffrey, 1969).

2) Most SMES suffer from the problem of paying all bills/cash outflow from cash earnings which most time remain a poor means of settlement other means not being ostensibly available to small firms posing a technical insolvency of the firm (Geoffrey,1969).

3) The small business experience situation where the production and sales cycle is shorter than the average age of account payable, in this situation, trade debt can build up in an ever increasing manner until a point is reached when it cannot be paid off in due date (Geoffrey, 1969. Anyanwu, 1996 Levy, 1993).

\section{Theory of working capital management and small scale business}

Akinwande (2010) averred that the management of working capital impacts on liquidity, investment portfolio and profitability. All these three factors are decisive in the growth or failure of a business. Hence, good performances in working capital management affects these decisive factors favourably and thus, contribute to growth and success of the business.

His work is based on the theory that efficient management of working capital is very vital for a business survival. This is premised on the fact that having too much working capital signifies inefficiency, whereas too little cash at hand signifies that the survival of the business is shaky

Abel (2008) examines the impact of working capital management on cash holdings of small and medium-sized manufacturing enterprises in Sweden. The aim of the work is to theoretically derive significant factors relating to working capital management which have an influence on the cash level of SMEs. He tested these with a large sample of Swedish manufacturing SMEs. The theoretical framework for his study consists of a treatise of motives for holding cash, working capital management and cash level. He discovered that efficient working 
capital is positively related to cash holding.

Generally, working capital policy is somewhat related to SMEs in terms of its operations. In relation to the profit motive reasons for which an owner-manager operates a business, there is no obligation to account for their actions in regard of working capital management. Thus, the management of working capital is influenced by this style of running the small enterprise. Operations of SMEs in Ghana were found to relate to the working capital policy in the quest to be efficient and timely.

\section{Research Question}

1) Do SMEs maintain appropriate working capital management policy system?

2) Is the failure of most SMEs a result of poor working capital management?

3) Is effective working capital management of value to the survival and solvency of the SMEs.

\section{Model specification and analysis}

There are standard and acceptable positions for working capital management in firms. However, this position is not stereotype it is based on nature of the firms, industry where the firm is operating, position of the firm in the industry, stages of the firms growth and generally acceptable norms in the industry.

However, in regard to our work Geoffrey (1969) we proposed standard an acceptable industrial average ratios for working capital management in the industry this is stated as follows:

\section{Ratios}

1. Current liability ratios in day

2. Current ratios

Quick ratio

3. Average age of trade debts:

\section{Standard}

Upper limit $<365$ days

Ratio 1:1

Ratio 1:1

Where $\mathrm{R}=$ Account Receivable

$\mathrm{Cs}=$ Credit sales expected during the period

4. Average account receivable (AR)
Average account payable
(AP)
$(\mathrm{AR}=\mathrm{AP})$

i.e. the average age of accounts receivable is less than those of trade credit, in this case the firm is financial healthy.

NOTE

The true identity of the two SMES is not stated, while firm A is into production, firm B is in service industry. This is used to show individuality of the various firms and their operation. It also serves as representative of firms in the two industries.

\section{Data Analysis}

Current liquidity ratio

Current ratio

Average age of trade debts

Average age of account payable

Analysis

FIRM A

From the analysis above it is clear that in firmA it will take 349 days to repay it creditors given the current level of cash earnings before tax. While firm B will only take 16 days to repay it own. Both firms are not doing seriously bad. Firm A will only repay it debt within 349 days almost a year, it goes to say that given any further short fall in cash receipt it will take over a year to be able to repay it debt back this is pushing the firm to a position of technical insolvency. Where as in firm B it will take only 16 days to repay current debt that is, the cash available could pay off current debt within every sixteen days. This is equally less acceptable, because it means there is no effective use of available cash. There is under trading in this firm.

There are much of idle fund available to the firm's (FirmA) shareholders; funds are not effectively utilized to improve the profit of the firm. Idle fund pose it own threat to the firm because it reduce the effective profit to the firm and hence constitute unused resources at the disposal of the firm.

The current ratio of firmA stands at 1.04, the acceptable standard according to our work for this type of firm should be ratio $2: 1$ with 1.04 to 1 ; this is a little case of liquidity that could be experienced by the firm. It goes to say that for every $\mathrm{N} 1.04$ of working capital the firm will pay $\mathrm{N} 1$ as debt. However, it should be noted that stock remain part of the current asset and stock is not a quick cash earning asset unlike cash and account receivable. 
The extent, therefore, of comfortability of this firm depends on the volume and value of stock in the current assets.

FirmA may not experience insolvency if the current pattern continues; however, there could be excess liquidity. Firm B shows a high position of overtrading ratio which stands at 23: 1 this is a position of overtrading; it means there is no effective use of resources. The profitability therefore of the firm is being maximized. The firm is over utilizing resources, at this position the firm is after profitability at the expense of liquidity.

The average age of trade debts is 6.3 days this goes to say that average trade debt remain unpaid for 6.3 days out of the standard 90 days. That is, trade debt is received every 6.3 days and this means that trade debt are received 8 times within three months. In firm B receipt is within every 11 days given 90 days payments period. It means most trade debt is received 8 times within three months this is an acceptable level for the firms the firms are doing right.

Average age of account payable in firm A is 3.6 days of standard 90 days. Firm A must settle it trade creditor ever 3.6 days and it means it will make payment 25 times within 90 days. While firm B pays every 7.2 days and 12.5 times within 90 days.

The above Scenario could provoke great insolvency for Firm A; it receives cash within 6.3 days and pay creditors within 3.6 days.

Firm B is in the same position it receives payment from debtor within 11 days and pay creditors with every 7.2 days. This could create strong liquidity squeeze for the firms, the solvency position of the two firms remain threaten, if the current Scenario is allowed to persist.

The two firms will have to work seriously on their credit policy and payment system to avail themselves of cash finance from trade credit.

\section{Conclusion}

1) It was evident that small firms have very weak financial position they rely on credit facility to finance their operation, this credit facility most times comes from account payable.

2) Most small firms become insolvent and fail because they often than not could not access financial assistance from the financial institutions due to lack of the necessary requirement needed by the financial institutions.

3) It was also revealed from this study that there is poor liquidity in most small business in Nigeria the small business have current assets in excess of current liability leading to shortage of fund .

4) There is also poor record keeping system in most small firm which reduces the ability of the firm to monitor the proper flow of their working capital.

5) The poor working capital flow of the smell firms have precluded them from the ability to compete effectively

6) from the study it was revealed that most Small business fail at most within 2 years, the strongest will fail within 6 years, while only few surviving ones remain.

\section{Recommendation}

The following recommendations are therefore made:

1) A strong credit policy system that will ensure that account receivable period is shorter than account payable period.

2) The maintenance of financial manager position within the firm to gauge the credit policy and debt repayment system of the firm, to ensure professional financial management practice within the firm. Where the firm is a small firm the service of a financial consultant could be engaged on regular basis to ensure strong financial position.

3) Periodic financial report should be prepared by the small business owner using the service of professional accountant; this will enable the entrepreneur to ensure strong financial position.

4) Good accounting record should be maintained by the entrepreneur to ensure that all financial transaction is tracked down to avoid leakage in financial transaction.

5) Cash should not be used as gauge for performance, but the financial report should be used rather to gauge performance. Most entrepreneurs only run on cash basis. They only monitor their cash position without taken cognizance of their debt position.

6) The government should make laws that would guide the debt recovery and credit payment system within Nigeria. The current system where your ability to recover debt depends on your firms aggressiveness and boldness left much to be desired.

\section{References}

Abel. (2008). Working Capital Management; SME; Cash Holdings; Cash substitute; Cash conversion. 
University essay from Mittuniversitetet/Institutionen för samhällsvetenskap.

Adeleke, Adepoju. (2003). Business Policy and Strategy Concept. Publications Ltd; Mushin Lagos.

Akinwande G. S. (2010). Working capital management in telecommunication sector. School of Management, Blekinge Institute of Technology.

Anao, R.A. (1990). Management Finance. UNIBEN Press, Nigeria.

Anderson, D. (1982). Small Industry in Development Countries: A Discussion of Issues. World Development, Vol. 10, No. 11. doi:10.1016/0305-750X(82)90034-1, http://dx.doi.org/10.1016/0305-750X(82)90034-1

Anyanwu C.M. (1996). Efficient Administration of Credit for Small Scale Industrial Development in Nigeria. Bullion, Vol. 20, No. 3 Central Bank of Nigeria.

Beeley, H. (1973). Industrial Management Services. Plymouth Macdonald and Evans Ltd.

Bolton, J.E. (1971). Report of Committee of Enquiry on Small Firms. United Kingdom.

Bumiro, A., \& Alos. (2001). The Success Story of an Entrepreneur (from Tantalizer).

Charles P. I. (1992). Introduction to Finance Management. IRWIN.

Gana Jonah S. (1995). Entrepreneur Jofegan Associate, Jos, Nigeria.

Geoffrey at al. (1969). Management of Money and Finance. Grower Press, New York.

Kehinde J., and Abiola J. (2005). Financial management and strategy. Rakson Educational publisher Lagos .

Lawal A. A. (1998). Entrepreneurship Development in Small Scale Business. LD Publisher.

Levy B. (1993). Obstacles to Developing Indigenous Small and Medium Enterprises: An Empirical Assessment. World Economic Review, Vol. 7, No. 1.

Nnanna O.J. (2005). The Importance of Small and Medium Scale Industry in Economic Development.

Ogundele O. J. k. (2004). Launching a business enterprise: in OJK Ogundele Introduction to business organization Molofin Nominees Lagos.

Ovia, Jim. (2001). Financing Nigeria's Digital Revolution via SMES. A Seminary by the U.S Embassy, Lagos.

Williams F. J. (1977). Elementary Business Statistics. Prentices Hall Inc., USA. 